\title{
Study on the Necessity and Feasibility of Offering Declamation Course to English Normal Students
}

\author{
Zhirong $\mathrm{Lu}$
}

\begin{abstract}
This paper analyses the current situation of the English normal students in English declaiming at full length, expounds the necessity of offering declamation course, and probes into the feasibility of offering the course. This finding shows declamation course plays an important role in improving normal students' pronunciation and intonation, cultivating their flow of speech and sense of language and enhancing their language infection. Therefore, it is necessary to offer declamation course to English normal students.
\end{abstract}

Index Terms-English declamation teaching, necessity, feasibility.

\section{INTRODUCTION}

The well-known saying "A teacher is the one with both high knowledge and moral integrity" by educationist Tao Xingzhi in China makes many English normal graduates worried and puzzled, because although they have excellent grades and various certificates, they cannot speak English correctly, fluently and infectiously, which means they cannot really conquer their prospective students. According to Xiaojie Luo, the most popular English teachers are those who not only have a good command of English language but also have standard, fluent and rhythmic oral English [1]. That many English normal students fail to meet the standards may to some extent result from the curriculum setting. What is the current situation of the declamation of English normal students? Is it necessary to offer declamation course? Is it feasible to offer the course to English normal students?

\section{The Current Situation OF ENGLish DeClamation}

\section{A. Current Curriculum Setting Failing to Stimulate Students to Declaim Correctly}

Although most universities offer the course of phonetics, it is very challenging for students to memorize and apply too many contents including the pronunciation of 48 phonemes, the theoretical knowledge of stress, liaison, pause, rhythm and intonation, etc within 32 periods. As a result, many students are unable to understand them, let alone to use them. Or maybe they just can memorize some of the phonemes. In other words, 32 periods' teaching and guiding are not long enough for them to form a good habit of declaiming. Without further guide, their pronunciation and intonation may even return to their original state.

Manuscript received March 10, 2014; revised May 13, 2014.

Zhirong Lu is with School of Foreign Studies, Yangtze University, Jingzhou, Hubei, China (e-mail: chenge970418@126.com).
Almost every university offers the course of spoken English to English majors to improve their oral English, and the universities even arrange teachers from USA or UK to teach them, however, the course emphasizes too much output of knowledge, and how could they realize language output without enough input? And because of timidity and inferiority, some students even miss the chance of speaking freely in class, and they just prefer to listen to the foreign teachers' speaking.

The course of intensive reading gives priority to the grasp and application of basic knowledge including grammar and writing, and the students just follow the teachers' advice and guidance to finish those exercises, consequently the chance for the students to read and know their own pronunciation errors is very slim.

In a word, these courses are not beneficial enough to cultivate students' ability to declaim.

\section{B. English Declamation Lacking Correct Guidance}

English normal students have already developed the habit of reading aloud in the morning, however, the lack of correct guidance results in their poor quality reading with special dialect tone, what's more, the intonations, pauses and stress sound very confusing and strange. The final consequence is what those students express cannot make themselves well understood and they cannot understand other's standard English either.

\section{The Necessity to OfFer Declamation Course}

English declamation is an artistic re-creative activity of turning silent works into verbal language with normal language as its target. It is not intuitive process of reading the words at the sight of them but a complex psychological and physiological process of reining language [2]. English declamation course attaches great importance to developing correct and fluent reading habit by imitating and appreciating beautiful English essays, speeches, stories, poems, movie dialogues read by native speakers.

The necessities of offering English declamation course for English normal students can be embodied from the following aspects:

\section{A. Bettering the Pronunciation and Intonation, \\ Strengthening the Sense of Language}

Offering English declamation course is beneficial to English normal students in enhancing their cognition of phoneme pronunciation, stress, liaison, pause, rhythm and intonation, as declaiming can make a deeper impression on students compared with pure phonetic course [3]. In other words, reading aloud makes a heavy cognitive demand on the 
learners [4], and that's why the phonetic knowledge is more unforgettable. What's more, in declamation course, students can apply their phonetic theoretical knowledge to declamation of articles so as to read in a correct and fluent way with the help of their teachers. According to Heli Zhang, a semester's article-declaiming training is of great help to the improvement of students' rhythm, especially stress, pause and strong and weak form, and it is of certain help to the improvement of students' English intonations, and even the students with poorer pronunciation have made obvious progress after the training [5].

According to the author's teaching practice to 81English normal students, after taking the course of declamation, the great majority of the students have already had a better command of the pause, the stress, liaison, intonation compared with their previous situation. Some previous problems have been solved gradually. And the phonetic problems to be solved are few and far between.

\section{B. Strengthening the Input of Language, Enriching the} Accumulation of Language and Improving Literary Quality

In Natural Approach, Famous educationist Krashen points out "The best methods are therefore those that supply 'comprehensible input' in low anxiety situations, containing messages that students really want to hear. These methods do not force early production in the second language, but allow students to produce when they are 'ready', recognizing that improvement comes from supplying communicative and comprehensible input, and not from forcing and correcting production [6]." That is to say input is more important than output. In the four basic language skills, listening and reading belong to input whereas speaking and writing belong to output. Declamation can help normal students appreciate the literary works in a pleasant way, which is much easier for them to accumulate knowledge and better their literary quality unconsciously.

\section{Improving the Ability in Oral Expression and Giving Play to Language Infection}

In Declamation Knowledge by celebrated Chinese announcer Zhang Song, he states that declamation is very helpful for people to better their language competence and give full play to language infection [7]. In English declamation class, normal students can feel the beauty of language and culture, and they will enjoy declaiming, gradually they will turn their original passive attitude into positive attitude because they will find they could speak out fluently what they have learned in standard English. Undoubtedly their expressing must be infectious and impressive, which may benefit their future students a lot.

\section{Cultivating Students' Courage and Confidence}

In the declamation classroom, the students can usually get a lot of chances to stand before their classmates to declaim or perform. If it is the first time for the students to perform, maybe they will feel worried or embarrassed, as a result, they dare not have an eye contact with their classmates, but once they frequently declaim and perform in the front of the classroom, they may gradually become courageous enough and confident. Therefore, especially to those students who are timid or shy or lacking in confidence, to take the declamation course is the blue moon for them cultivates their courage and confidence.

\section{The FEASIBILITY OF OFFERING ENGLISH DECLAMATION}

Declamation is not only a process of cognition and exchange of language, but also an extremely complex psychological activity. The premise of effective declamation is the solid phonetic knowledge. The university where the author works offers the course of phonetics in the first term for freshmen, and offers declamation course in the second term, which is well-received by normal students. The feasibility can be reflected in the following aspects:

\section{A. The Contents Involving Various Types and Rich Themes}

Catering to the age characteristic and the psychological features of college students, the contents of declamation course involve five different literature types including essays, stories, poems, movie dialogues and speeches, and cover rich themes, such as the pursuit of dreams, the appreciation of life, the exploration of growth, which can to a large degree offer college students a wonderful chance to imitate the standard pronunciation and appreciate the beauty of the literary works. As a result, the declamation course play an indispensable role in cultivating their taste, infecting their soul and inspiring their thoughts. Exposed in the such a kind of contents, one couldn't help declaiming the beautiful, inspiring and significant articles, poems and speeches.

\section{B. Urging Students' Comprehension of the Contents}

The precondition to declaim an article correctly and infectiously is comprehension while declamation class cannot offer students enough time to comprehend the contents, therefore preview is very indispensable. For those students who are unwilling to understand the article before their declamation, their imitation is doomed to be a failure. Take "First Inaugural Speech" by John F. Kennedy for example, if you have no idea of his social and educational background, or even worse, if you have no idea about who he is, how could you read the speech in a passionate and infectious way? If you have no idea of his speech, how could you give correct pause, stress and intonation to the sentence? Hence, to take declamation course can urge students to develop a good habit of comprehending some beautiful English articles.

To appreciate the article means consulting different dictionaries and reference books concerned or surfing the internet, gradually and consequently, the students knowledge can be enriched and horizon can be broadened.

\section{Emphasizing Phonetic Theoretical Knowledge and Comparison Teaching Method}

While guiding students' declaiming the articles, teachers had better urge them to recall and conclude the phonetic theoretical knowledge of stress, pause, liaison and intonation so as to make them deeply impressed by the theoretical knowledge, which is sure to promote their effective declaiming in their spare time. Take the following article "Abundance Is a Life Style" written by Catherine Franz [8] for example: 
"Be in a state of abundance of what you already have. I guarantee they are there; it always is buried but there. Breathe them in as if they are the air you breathe because they are yours. Let go of anything that isn't abundant for the time being..."

When students listen to and imitate the above paragraph, such questions as "What kind of theoretical phonetic knowledge has been used here? Could you point out the example from this paragraph to illustrate liaison, assimilation, strong form and weak form principles?..." can be raised, and then try to ask some students to answer the questions. If students cannot give the exact answers, it is the very time to offer the correct answers. In the first sentence of this example, there are three liaisons and one assimilation. That is to say, "in "and "a", "state" and "of", "of" and "abundance" should be linked smoothly and fluently. And the assimilation is between "what" and "you". In the third sentence, "in", "are" and "yours" as form words usually needn't be stressed, but in this sentence they need to be stressed, because these form words are at the end of a sentence or are used to emphasize something. In order to help students to apply the theoretical phonetic knowledge, it is a good chance to help students review the theoretical phonetic knowledge and reinforce their memory and application.

Comparison teaching method can usually enhance students' cognition. In declamation class, students can understand and pronounce the similar but different phonemes better by comparison, such different pronunciation as "see" and "say", "light' and "night", "sin and sing", etc. The shifts of stress in a word result in different parts of speech and different meanings; Changing the place of stress of words in the sentence also has different implications, the same is true of changing the place of pause, so is changing the intonation of sentence [9].

Besides, it is necessary to emphasize the phonetic features of each lesson. Some lessons may emphasize the liaison, some lessons may highlight the different intonations, others may give emphasis on the rhyme. For instance, the poem "The Road Not Taken" by Robert Forst has 4 stanzas, and each stanza has 5 lines with a rhyming of ABAAB, and each line has 9 syllables. Teachers can always first point the phonetic features so as to remind students of what they need to pay special attention to, or they can ask students to sum up the phonetic features. In this way, students can have a better understanding of each lesson's phonetic features and when they imitate the standard record or when they declaim, these phonetic features can be more instrumental.

\section{Carrying out Group Instruction, Emphasizing Drama, Movie Dubbing Performance}

A class can be divided into several groups based on the matching of different genders and students from different areas, which can promote the mutual help. Students of different genders and from different places may attract each other and have their own typical strong points and weak points in phonetics. In order to make sure the assignment is fulfilled, a group leader can be appointed to take charge of it. The group leader can organize the drama and movie dubbing performance, and different groups can compete with each other, which to a large degree can stimulate their desire to win. And if all of them want to be the winner, they have to imitate the standard record repeatedly. Undoubtedly, what they have done will contribute to their fluent declamation and expression.

Of course, the group performance in drama or movie dubbing is supposed to be in the front of classroom, because this kind of performance not only can cultivate their ability to cooperate and coordinate, but also can cultivate their courage and confidence.

\section{E. Implementing Various Effective Testing Mechanism}

Prior knowledge assessment is very important for both the students and the teachers [10]. For the students, through the assessment, they can know their weak points as well as their strong points so as to better themselves and strengthen their confidence; for the teachers, they will have a clear idea of which knowledge they should emphasize so as to help students to grasp and what kind of teaching method they should apply so as to make the knowledge more acceptable. Therefore, it is very necessary to design some tests to assess students at the very beginning of each lecture.

A survey according to the author's teaching shows only $25 \%$ students are willing to declaim if teachers do not give them declaiming assignment. That is to say without pressure the majority of the students are reluctant to read, which indicates that designing and arranging testing mechanism for students are very necessary. The test that may last 10 to 20 minutes is usually arranged at the very beginning of each class, and the testing content covers the prior knowledge. If the student can declaim what he/she has learnt in standard English, he/she can get the highest mark; if he/she fails, then poor mark, which will be taken into consideration in their final grades. As a result, this kind of test not only can urge students to review what they have learnt, but also can make teacher realize in their teaching whether they still need to improve some aspects or not. Through the teaching practice, this testing mechanism does work well.

Besides, to urge students to record their declamation and hand in their record is also a very effective way to assess and help improve their pronunciation and intonation, because every enterprising student must declaim their articles for numerous times before they start to record their declamation, if they want to show the best of them before their classmates.

\section{F. Introducing the Evaluation Mechanism to Declamation Teaching}

Classroom evaluation is vital. Combining the evaluation mechanism among students and teachers' evaluation is a very effective method to remind students of their strong points and weak points in phonetics. After a student finishes his/her declamation, the teacher can first ask several students to make some comments on his/her reading, psychologically speaking, this method can impress the students most, especially when he/she has realized his errors. Meanwhile, if the students in charge of giving comments cannot point out the weak points, it also shows they also have the similar weak points. To a large degree, this can promote them to have a clear realization about their current phonetic situation. What's more, the evaluation that the normal students have given can lay solid foundation for their future teaching career, as from the experience they also can learn how to give their future students some comments in their teaching. 
Naturally, the teacher's evaluation is very necessary, because he/she can make most of the chance to re-mention the phonetic theoretical knowledge and say something encouraging to make students see their potentials so as to stimulate the students' enthusiasm to declaim and express better.

\section{CONCLUSION}

In declamation class, English normal students not only can have some perceptual cognition of phonetics, but also can have some theoretical cognition by listening, imitating, performing and evaluating, which can help them achieve the standards: having beautiful and correct pronunciation, possessing fluent and infectious language [1]. Meanwhile, by taking declamation course, the English normal students can also have rich literature cultivation and the ability to appreciate literary works.

In order to make English normal students benefit most, it is necessary to meet the following three needs: firstly, the time of the declamation course had better be set in the second semester, especially after they have already taken the phonetic course; secondly, the place of the course had better be set in a multi-media classroom; thirdly, the teachers had better possess the beautiful pronunciation and be proficient in phonetics.

\section{REFERENCES}

[1] X.-J. Luo, "The most popular english teachers among secondary school students," English Language Teaching and Studying in Elementary and Secondary Schools, 2002
[2] S.-W. Li, "Teaching exploration on English declamation," Yulin Normal College Journal, vol. 23, pp. 117-120, 2002.

[3] X.-J. Su, "On the university English reading," Journal of Nanchang College of Education, vol. 28, pp. 158-159, 2013.

[4] K. J. Keys, "Inter-language phonology theoretical questions and empirical data," Linguagem \& Ensino, vol. 5, no. 1, pp. 86, 2002.

[5] H.-L. Zhang, "An empirical study of the effect of article reading training on English pronunciation," Journal of Luoyang Institute of Science and Technology, pp. 58-60, Feb 2009.

[6] S. D. Krashen, Principles and Practice in Second Language Acquisition, Prentice-Hall International, 1987.

[7] S. Zhang, Declamation Knowledge, Communication University of China, Jan. 2010.

[8] M.-H. Yu, Born to Win, Zhejiang Education, January, pp. 70-72

[9] S.-F. He, Practical English Phonetics, Peking Normal University, April 1991, pp. 128-143.

[10] T. A. Angelo and C. K. Patricia, Classroom assessment techniques: A handbook for college teachers (2nd edition), San Francisco: Jossey-Bass Publishers, 1993.

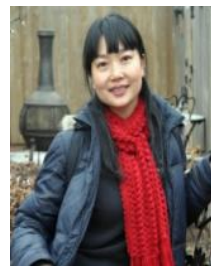

Zhirong Lu graduated from English Department of Huazhong Normal University, Wuhan, China with a degree of bachelor of arts in 1995; she received her M.A. in linguistics and applied linguistics from the same university in 2003. Later on, she visited and studied in Wesley College in Iowa USA from Aug.2008 to Feb.2009.

She has been working in School of Foreign Studies, Yangtze University, Jingzhou, Hubei, China as an English teacher since 1995. In 2006, she became an associate professor. One of her recent books is A Practical Course for English Pronunciation and Intonation, Press of Huazhong Normal University, Aug. 2011. As an English teacher for English majors, her studies and interests include English teaching and English phonetics. 